\title{
ASSISTIVE TECHNOLOGIES FOR PUPILS WITH VISUAL IMPAIRMENT BASED ON INFORMATION AND COMMUNICATION TECHNOLOGIES
}

\section{Vojtech REGEC}

\begin{abstract}
The contribution deals with the problem of assistive technologies in the educational context of pupils with visual impairment. In addition to their general definitions according each models, assistive technologies based on information and communication technologies are presented in more detail. Selection of appropriate technology determines a pupils' individual needs, technology platform of an education background and the functional mechanisms of the educational system. The aim of the activity becomes a full fledged participations of pupil with visual impairment in the learning process.
\end{abstract}

Key words: assistive technology, information and communication technologies, visual impairment, pupil.

\section{ASISTENČNÉ TECHNOLÓGIE PRE ŽIAKOV SO ZRAKOVÝM POSTIHNUTÍM NA BÁZE INFORMAČNÝCH A KOMUNIKAČNÝCH TECHNOLÓGIÍ}

Resumé: Príspevok popisuje problematiku asistenčných technológií v kontexte edukácie žiakov so zrakovým postihnutím. Okrem ich obecného vymedzenia podl'a jednotlivých modelov sú podrobnejšie predstavené asistenčné technológií na báze informačných a komunikačných technológií. Výber vhodnej technológie determinuje žiak a jeho individuálne požiadavky, technologické zázemie edukačnej platformy a tiež funkčné mechanizmy vzdelávacieho systému. Ciel’om pôsobenia sa tak stáva plnohodnotná participácia žiaka so zrakovým postihnutím v procese jeho vzdelávania.

Klićčová slova: asistenčná technológia, informačné a komunikačné technológie, zrakové postihnutie, žiak.

\section{1 Úvod}

Informačné a komunikačné technológie (ICT) a ich vplyv na rozvoj asistenčných technológií predstavujú klúčový význam vo vzdelávaní žiakov so zrakovým postihnutím. Zmeny, ktoré nám prinášajú asistenčné technológie na báze ICT prinášajú nielen nové výzvy a možnosti vo vyučovaní žiakov so zrakovým postihnutím, ale aj niektoré otázky, ktorých riešenie predpokladá spoluprácu všetkých participujúcich zložiek. Asistenčné technológie sa tak dostávajú do pozornosti rodiny žiaka, bežných pedagógov, špeciálnych pedagógov, sociálnych pracovníkov, pracovníkov neziskových organizácií, ako aj predajcov týchto technológií. V úplnom centre pozornosti ale nestojí len technológia ako napríklad hlasový odčítač, ale predovšetkým samotný žiak, ktorý asistenčnú technológiu využíva.

\section{Vymedzenie asistenčných technológií}

Pierangelo a Giuliani (2007 In Maanum, 2009) považujú za asistenčné technológie ( $\mathrm{z}$ angl. assistive technology) akékol'vek zariadenia, ktoré môže jednotlivec so zdravotným postihnutím použit' $\mathrm{k}$ vyriešeniu problému, alebo $\mathrm{k}$ zlepšeniu jeho schopností a zvýšit' tak svoju nezávislost'.

Podl'a Betancura (2008) asistenčné technológie zahrňujú asistenčné, adaptačné a rehabilitačné prostriedky a tiež proces používania pri ich výbere a používaní. V uvedenom ponímaní vyjadrujú asistenčné technológie, také technológie, ktoré zvyšujú nezávislost' $\mathrm{v}$ živote (prekonávanie informačných a technických bariér) a produktivitu l'udí so zdravotným postihnutím.

$\mathrm{V}$ praxi $\mathrm{z}$ dôvodu kladenia akcentu na spoločenský dopad sa do pozornosti stále častejšie dostáva predovšetkým sociálny model definícií asistenčných technológií, ktorý poukazuje predovšetkým na preklenutie bariér s ciel'om poukázat' na potenciálne možnosti jednotlivca so zdravotných postihnutím pri aktívnej participácii $\mathrm{v}$ existujúcej sociálnej infraštruktúre intaktných (Hersh a Johnson, 2008). 


\subsection{Komprehenzívny model asistenčných technológií}

Cook a Hussey (2002 In Hersh a Johnson, 2008) nazerajú na celé spektrum asistenčných technológií ako na variabilný mechanizmus, ktorý pomáha pri začleňovaní jednotlivca so zdravotným postihnutím do spoločnosti. Kl'účovým sa tak stáva samotný jednotlivec a jeho aktivita $v$ kontexte. $\mathrm{Na}$ základe tejto premisie bol vytvorený HAAT (Human Activity Assistive Technology) model, na ktorého podklade vzniká celistvý CAT (Comprehensive Assesstive Technology) model, ktorý predstavuje komplexný rámec ponímania asistenčných technológií. Hersh a Johnson (2008) popisujú oba modely ako systém, ktorý je vytvorený z nasledujúcich štyroch zložiek:

1. Kontext (Context) - predstavuje sociálnu štruktúru prostredia a individuálne vlastnosti jednotlivca, ktoré majú vplyv na používanie asistenčnej technológie.

2. Jednotlivec (Human Person) - vyjadruje centrum HAAT modelu so zretel'om na individualitu osobnosti. Usiluje sa okrem izolovaného technologického konštruovania platformy asistenčnej technológie tiež neprehliadat' dizajn $\mathrm{z}$ pozície jednotlivca (Human-centred design).

3. Aktivita (Activity) - popisujú oblast' používania a ciele, ktoré si jednotlivec želá dosiahnut'. Zložka aktivity je výrazne flexibilná a má zásadný vplyv na HAAT model.

4. Asistenčná technológia (Assitive Technology) - označujú jednotlivé prekážky a bariéry, ktoré je potrebné prekonávat' $\mathrm{v}$ kontexte.

Grafické znázornenie HAAT modulu prezentujeme na nasledujúcom obrázku.

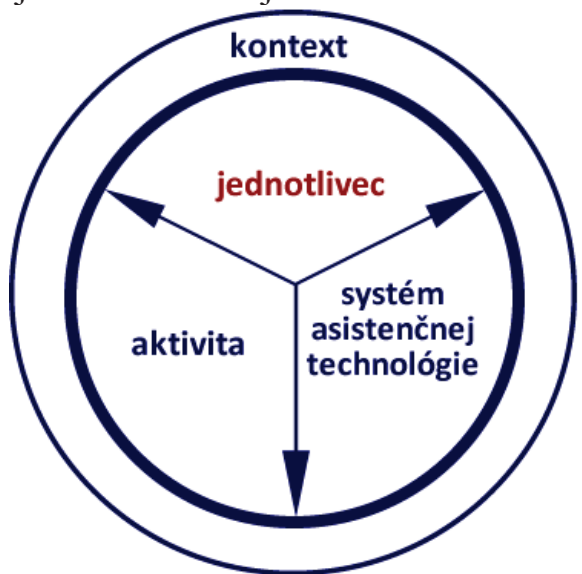

Obr 1: HAAT model systému asistenčných technológii podla Cooka a Husseya (2005 In Hersh, Johnson, 2008)
Komprehenzívny model asistenčných technológií (CAT model) tak následne dokresluje, že primárnym determinantom štruktúry bude samotný jednotlivec a jeho aktivity v spoločenskom kontexte.

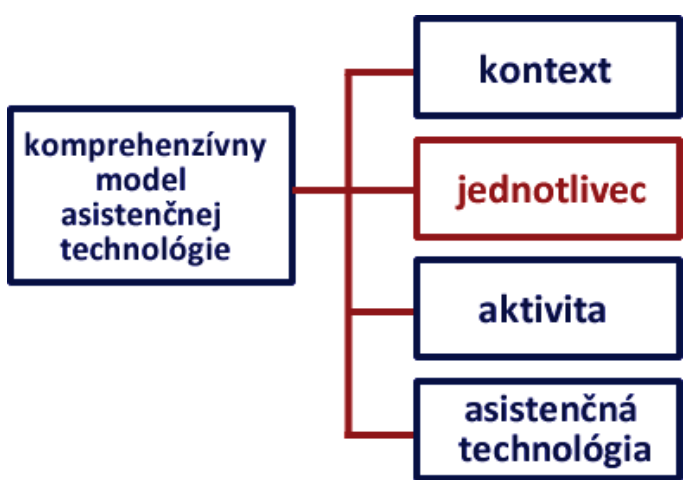

Obr 2: Komprehenzivny model asistenčných technológií podl'a Hersha a Johnsona (2008)

Z hl'adiska kontextu pracovného uplatnenia vytvárajú asistenčné technológie príležitosti k odstraňovaniu bariér. V školskom prostredí predstavujú asistenčné technológie dôležitý prostriedok $\mathrm{V}$ procese integrácie žiakov so zdravotným postihnutím. Loewen (2010) hovorí o nasledovných zmenách, ktoré prinášajú asistenčné technológie:

- „eliminácia závislosti jednotlivcov so zdravotným postihnutím od priamej podpory intaktných osôb $\mathrm{v}$ oblasti čítania, písania a komunikácie (Barclay, Lilburn, Loewen,Nobel \& Tomassetti, 2002; Burstahler, 2003),

- zvýšenie produktivity (O'Halloran, 2009),

- podpora samostatnosti (Burgstahler, 2003; Zabala, 1990),

- širšia ponuka participácie v majoritnej spoločnosti intaktných pri zamestnávaní jednotlivcov $\mathrm{S}$ postihnutím $\mathrm{v}$ dospelosti (Illinois Assistive Technology Program, 2005; Loy \& Batiste, 2008)“ (s. 24).

\section{Asistenčné technológie a žiak so zrakovým postihnutím}

$\mathrm{V}$ edukačnom prostredí je podpora žiakov so zrakovým postihnutím $\mathrm{z}$ hl'adiska používania asistenčných technológií determinovaná individuálnymi požiadavkami žiaka. Na strane druhej významnú oblast' z hl'adiska dostupnosti prostriedkov v praxi (ako aj možnosti saturácie individuálnych potrieb žiaka) predstavuje vývojový stupeň technologického zariadenia. Purcell a Grant (In Maanum, 2009) hovorí o tzv. 
„starších“ technologických zariadeniach („low" technology devices), ktoré nepotrebujú elektronické prostriedky, zvyčajne sú l’ahko dostupné, a to vrátane finančných nákladov. Naopak „moderné“ technologické zariadenia (,high" technology devices) vyžadujú elektronickú podporu a sú cenovo náročnejšie.

Asistenčné technológie môžeme $\mathrm{v}$ širšom kontexte popisovat' ako všetky skonštruované prostriedky, ktoré čiastočne alebo úplne riešia problém jednotlivcov so zrakovým postihnutím $\mathrm{v}$ takých oblastiach, ktoré vznikli ako dôsledok zrakového postihnutia.

Medzi takéto prostriedky patria napríklad:

- dioptrické okuliare, d'alekohl'adové okuliare, lupa, turmon;

- pražská tabul'ka, kolíčková písanka;

- pichtov písací stroj;

- kniha na magnetickom nosiči, kniha na optickom disku;

- kalkulačka s audio výstupom;

- náramkové hodiny s taktilným alebo audio výstupom;

- meracie pásmo s audio výstupom;

- didaktický materiál na báze hmatových modelov;

- diktafón, MP3 prehrávač;

- indikátor hladiny;

- ozvučená lopta;

- zariadenie na rozpoznávanie farieb (ColorTest);

- zariadenie na identifikovanie predmetov (tzv. Sherlock);

- zariadenie pre tvorbu taktilných reliéfov (napr.: Zy-fuser);

- a iné.

$\mathrm{V}$ užšom ponímaní $\mathrm{z}$ aspektu prístupnosti a práce $\mathrm{s}$ elektronickými informáciami predstavujú asistenčné technológie kombináciu špeciálneho programu a technického zariadenia, resp. takej technológie, ktorá umožňuje osobe so zrakovým postihnutím $\mathrm{v}$ rámci ich individuálnych možností využívat' prostriedky ICT.

Kontext ICT a asistenčných technológií rozdel'ujeme do nasledujúcich štyroch základných rovín.

1. Asistenčné technológie, ktoré pri vytvorení vhodných podmienok fungujú $\mathrm{v}$ bežnom prostredí ICT a umožňujú následne ich používanie ako intaktným (napríklad: hlasový odčitač, braillský zobrazovač $\mathrm{v}$ prostredí bežného operačného systému a používanie jeho programového vybavenia ako MS Office Word a pod.).

2. Asistenčné technológie, ktoré pri vytvorení vhodných podmienok fungujú $\mathrm{v}$ bežnom prostredí ICT a umožňujú používanie softvérových riešení pre jednotlivcov so zrakovým postihnutím (napríklad: hlasový odčítač, braillský zobrazovač v prostredí bežného operačného systému a používanie editoru Lambda pri práci s matematickými zápismi, webový prehliadač WebbIE a pod.).

3. Asistenčné technológie vytvorené na báze ICT, ktoré sú konštrukčne uspôsobené primárne pre jednotlivcov so zrakovým postihnutím. Tieto technológie sú zväčša kompatibilné s bežnými prostriedkami ICT (napr.: GIN, Eureka ai.).

4. Asistenčné technológie vytvorené na báze ICT, ktoré sú konštrukčne uspôsobené pre jednotlivcov so zrakovým postihnutím a zároveň umožňujú prístup $\mathrm{k}$ bežným ICT, ktoré používajú intaktný (napríklad AutoLektor).

Model znázornenia asistenčnej technológie ako súčast' iných technológií ilustrujeme na obrázku 3.

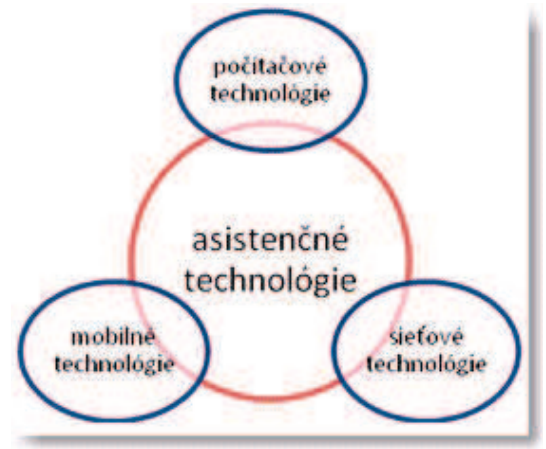

Obr 3: Asistenčné technológie ako súčast' iných technológii podl'a Regeca (2010)

Zvyšujúci sa počet asistenčných technológií sa premieta nielen do nárastu kvantity aktivít (tabul'ka 1), ktoré tieto technológie sprístupňujú (napr. vývoj nových špeciálnych softvérov a zariadení), ale predovšetkým do oblasti kvality týchto technológií (napr. nové funkcie odčítača obrazovky pre prácu s internetom ako podpora dynamických prvkov internetových aplikácií WAI-ARIA a d’alšie).

\begin{tabular}{|l|l|l|}
\hline $\begin{array}{c}\text { oblast' } \\
\text { (kontext) }\end{array}$ & \multicolumn{1}{|c|}{ aktivita } & \multicolumn{1}{c|}{ prostriedok } \\
\hline $\begin{array}{l}\text { získavanie } \\
\text { informácií }\end{array}$ & $\begin{array}{l}\text { čítanie novín, } \\
\text { časopisov, }\end{array}$ & $\begin{array}{l}\text { počítač, skener, } \\
\text { internet, }\end{array}$ \\
\hline
\end{tabular}




\begin{tabular}{|c|c|c|}
\hline $\begin{array}{l}\text { podpora } \\
\text { komunikácie }\end{array}$ & \multirow{3}{*}{$\begin{array}{l}\text { literárnych diel, } \\
\text { virtuálna } \\
\text { komunikácia } \\
\text { s okolím, } \\
\text { vyhl'adávanie } \\
\text { dopravných } \\
\text { spojení, } \\
\text { navigácia pri } \\
\text { cestovaní, } \\
\text { nakupovanie, } \\
\text { atd'. }\end{array}$} & \multirow{3}{*}{$\begin{array}{l}\text { operačný } \\
\text { systém, webov'́ } \\
\text { prehliadač, } \\
\text { odčitač } \\
\text { obrazovky, } \\
\text { braillský } \\
\text { zobrazovač, } \\
\text { zväčšovacie } \\
\text { softvér, digitálna } \\
\text { lupa, } \\
\text { OCR program } \\
\text { mobilný telefón } \\
\text { navigačná } \\
\text { jednotka GPS, } \\
\text { atd'. }\end{array}$} \\
\hline $\begin{array}{l}\text { podpora } \\
\text { mobility }\end{array}$ & & \\
\hline $\begin{array}{l}\text { podpora } \\
\text { samostatnosti }\end{array}$ & & \\
\hline
\end{tabular}

Tab 1: Asistenčné technológie ako prostriedok $v$ jednotlivých oblastiach podpory a ziskavania informácii

$\mathrm{Na}$ poli vzdelávania môže byt' edukačná platforma prístupná počítačovým a siet’ových technológiám, avšak nemusí byt' automaticky vhodne adaptovaná z aspektu prístupnosti aj pre asistenčné technológie (obrázok 4).

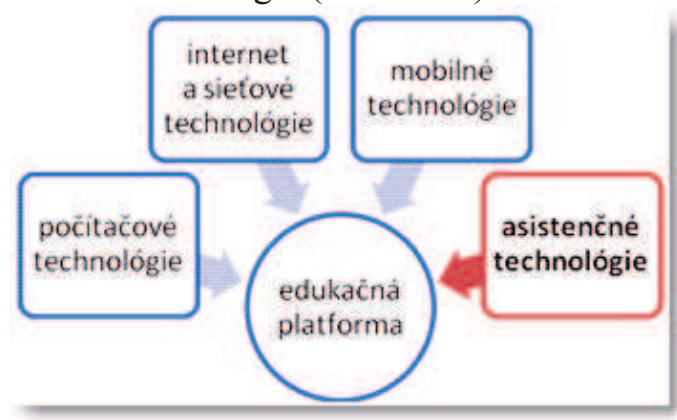

Obr 4: Asistenčné technológie ako jeden zo spôsobov prístupu $k$ edukačnej platforme podl'a Regeca (2010)

Jeníčková (1998) tvrdí, že s nástupom a vývojom výpočtovej techniky sa osobám so zrakovým postihnutím otvorili nové možnosti $\mathrm{v}$ celom procese socializácie. Ako d’alej uvádza vd’aka počítačom a špeciálnym technickým prídavným zariadeniam ako aj technologickému pokroku môžu jednotlivci so zrakovým postihnutím nielen študovat', ale po štúdiu sa pracovne uplatnit' a sebarealizovat' vo väčšom počte profesií ako v minulosti. Dôvodom bolo napríklad problematické získavanie informácií $\mathrm{v}$ prístupnej forme bez asistencie intaktných. Materiál v čiernotlači bolo potrebné nahovorit’ na magnetofóne, alebo adaptovat' a následne vytlačit' $\mathrm{v}$ bodovom písme.

Medzi najviac rozšírenú, oblúbenú ako aj uplatňovanú asistenčnú technológiu na báze ICT môžeme podla Růžičkovej (2006) označit' práve počítač. Ludíková (2004, s. 140) uvádza, že „,nevidiaci človek mal dostupné informácie iba pomocou sluchu a hmatu, teda $\mathrm{v}$ podobe hlasu a bodového písma a nebol schopný bez pomoci druhých akúkol'vek informáciu získat'. Dnes už môže vd'aka využitiu počítačov s hlasovým alebo hmatovým výstupom prijímat' širokú ponuku nielen informácií $\mathrm{z}$ bežného života, ale aj pracovat' $\mathrm{s}$ najrôznejšími vzdelávacími programami. Rovnako aj pre slabozrakých sa dostupnost' informácií vd’aka vybaveniu počítačov zväčšovacími programami a ozvučením celkom zmenila“.

Bubeníčková (2002, s. 227) popisuje význam počítača so špeciálnym programovým a technickým vybavením pre zrakovo postihnutých v oblastiach:

- „samostatnosti pri získavaní a spracovávaní informácií,

- vo viacúčelovosti použitia (čítanie, písanie, aktualizovanie, vyhl'adávanie),

- v mnohostrannom použití:

○ pomáha práve osleplým v účelnom naplnení vol'ného času po strate či prerušeniu zamestnania

- pomáha $\mathrm{v}$ následnej rekvalifikácii, prípadne štúdiu,

- pomáha pri výkone zamestnania“.

V závislosti od stupňa poškodenia zraku môžu podl'a Jaškovej (2008) jednotlivci so zrakovým postihnutím použivat' na príjem informácií nasledujúce techniky:

- „V prípade absolútnej slepoty používajú audio-taktilné techniky,

- v prípade zachovaného svetlocitu a t’ažkej slabozrakosti používajú audio-taktilné, $\mathrm{v}$ ojedinelých prípadoch, pri orientácii a mobilite, audio-vizuálne techniky,

- stredne a l'ahko slabozrakí a čiastočne vidiaci používajú prevažne špeciálne vizuálne, niekedy audio-taktilné techniky“" (s. 14).

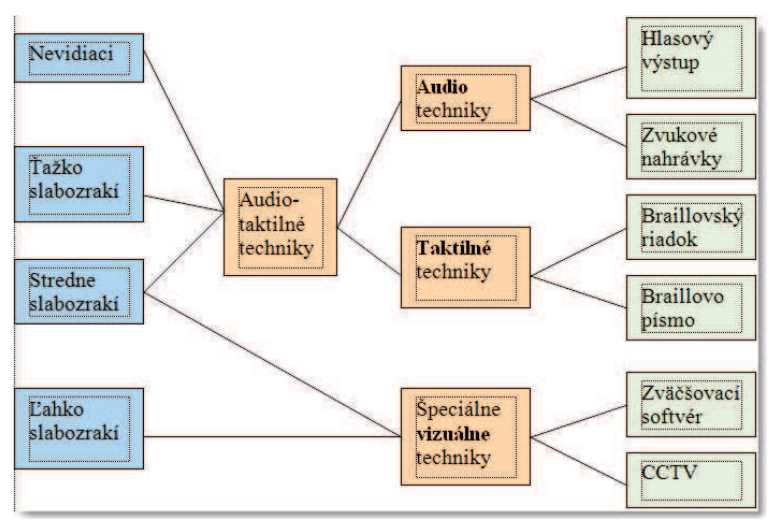


Obr 6: Typy technik sprostredkovania informácii u jednotlivcov so zrakovým postihnutím podl'a Jaškovej (2008, s. 15)

\section{Závěr}

Asistenčné technológie majú pre žiakov so zrakovým postihnutím nezastupitel'né miesto pri samostatnej práci s elektronickými informáciami. Proces transformácie elektronických informácií do prístupnej podoby sa neustále zdokonal'uje, a to v súčinnosti so samotnou inováciou technických zariadení, programových riešení a operačných systémov.

Vd'aka vysokej kompatibilite nových technológií s programovým vybavením pre bežnú populáciu majú žiaci so zrakovým postihnutím ovel'a väčšie možnosti v oblasti edukácie a taktiež pri interakcii so spoločenským prostredím. Asistenčné technológie totiž umožňujú žiakom so zrakovým postihnutím pracovat' $\mathrm{s}$ elektronickými informáciami rovnako efektívne ako intaktný.

$\mathrm{V}$ prípade, že sa škola u žiaka so zrakovým postihnutím nezaujíma o používanie asistenčných technológií vzniká následne riziko, že žiak bude mat' osvojené neefektívne techniky práce s ICT. Rovnako môžu byt' vytvorené také stereotypy v oblasti používania programov, ktoré bránia tvorivému využitiu ich potenciálu. Vzhl'adom k významu moderných technológií pre jednotlivcov so zrakovým postihnutím tak rastie riziko narušenia plynulého procesu socializácie, práve $\mathrm{z}$ dôvodu nízkej úrovne kompetencií v oblasti používania asistenčnej technológie.

\section{Literatura}

[1] BETANCUR, L. Canada: Requirements for Assistive Technology for Students with Special Needs. [on-line]. U.S. Department of Commerce, 2008. 3 s. [cit. 2012-02-03]. Dostupné na WWW $<$ http://www.buyusa.gov/canada/en/studentswiths pecialneeds.pdf $>$.

[2] BUBENÍČKOVÁ, H. Význam informačných a komunikačných technológií v edukační a rehabilitační procesu zrakově postižených. In JESENSKÝ, J. Edukace a rehabilitace zrakově postižených na prahu nového milénia. $1 \mathrm{Vyd}$. Hradec Králové: Gaudeamus, 2002. s 222 - 235. ISBN 80-7041-041-8.

[3] HERSH, M.A., JOHNSON, M.S. (Eds.). Technology for Visually Impaired and Blind
People. 1 Vyd. London: Springer-Verlag. 2008. 725 s. ISBN 978-1-84628-866-1.

[4] JAŠKOVÁ, L'. Digitálne technológie vo vzdelávani zrakovo postihnutých. Bratislava: Univerzita Komenského, 2008. 158 s. [Dizertačná práca.]

[5] JENÍČKOVÁ, J. Počítače a nevidomí. In Speciálni pedagogika. Časopis pro teorii a praxi speciální pedagogiky. Praha: Pedagogická fakulta, UK v Praze, 1998. Roč. 8, Číslo 4. s. 2932. ISSN 1211-2720.

[6] LOEWEN, G. Technology Matters: Creating Usable Working Environments. In NEADS: Success in STEM: Studying and Pursuing a Science or Technology Career as a PostSecondary Student with a Disability. 1 Vyd. Ottawa: National Educational Association of Disabled Students (NEADS), 2010. s. 24 - 30. ISBN 978-0-9686659-5-4.

[7] LUDÍKOVÁ, L. Dítě se zrakovým postižením. In MÜLLER, O. a kol. Ditě se speciálními vzdělávacími potřebami v běžné škole. 1 Vyd. Olomouc, Univerzita Palackého v Olomouci, 2004. s. 123 - 144. ISBN 80-2440231-9.

[8] MAANUM, J.L. The General Educator's Guide to Special Education. 1 Vyd. California: Corwin Press, 2009. 236 s. ISBN 978-1-41297137-9.

[9] REGEC, V. Prístupnost' elektronických informácii pre śtudentov so zrakovým postihnutím. Bratislava: Univerzita Komenského v Bratislave, 2010. 145 s. [Rigorózna práca.]

[10] REGEC, V. Praktické využitie informačných a komunikačných technológii u žiakov so zrakovým postihnutím. Olomouc: Univerzita Palackého v Olomouci, 2010. 244 s. [Dizertačná práca. ]

[11] RŮŽIČKOVÁ, V. Integrace zrakově postiženého žáka do základni školy. Olomouc, Univerzita Palackého v Olomouci, 2006. 73 s. ISBN 80-244-1540-2.

PhDr. Vojtech Regec, Ph.D.

Ústav speciálněpedagogických studií

Pedagogická fakulta UP

Žižkovo nám. č. 5

771 40, Olomouc, ČR

Tel: 00420585635323

E-mail: regecv@gmail.com,

Www pracoviště: www.uss.upol.cz 